\title{
NOTA
}

\section{SPATIAL VARIABILITY OF SOIL CHEMICAL PROPERTIES AFTER COFFEE TREE REMOVAL ${ }^{(1)}$}

\author{
Sidney Rosa Vieira ${ }^{(2)}$, Osvaldo Guedes Filho(3), Márcio Koiti Chiba ${ }^{(2)}$ \\ \& Heitor Cantarella ${ }^{(2)}$
}

\begin{abstract}
Assessing the spatial variability of soil chemical properties has become an important aspect of soil management strategies with a view to higher crop yields with minimal environmental degradation. This study was carried out at the Centro Experimental of the Instituto Agronomico, in Campinas, São Paulo, Brazil. The aim was to characterize the spatial variability of chemical properties of a Rhodic Hapludox on a recently bulldozer-cleaned area after over 30 years of coffee cultivation. Soil samples were collected in a $20 \times 20 \mathrm{~m}$ grid with 36 sampling points across $\mathrm{a} 1 \mathrm{ha}$ area in the layers $0.0-0.2$ and $0.2-0.4 \mathrm{~m}$ to measure the following chemical properties: $\mathrm{pH}$, organic matter, $\mathrm{K}^{+}, \mathrm{P}, \mathrm{Ca}^{2+}, \mathrm{Mg}^{2+}$, potential acidity, $\mathrm{NH}_{4}-\mathrm{N}$, and $\mathrm{NO}_{3}-\mathrm{N}$. Descriptive statistics were applied to assess the central tendency and dispersion moments. Geostatistical methods were applied to evaluate and to model the spatial variability of variables by calculating semivariograms and kriging interpolation. Spatial dependence patterns defined by spherical model adjusted semivariograms were made for all cited soil properties. Moderate to strong degrees of spatial dependence were found between 31 and $60 \mathrm{~m}$. It was still possible to map soil spatial variability properties in the layers $0-20 \mathrm{~cm}$ and $20-40 \mathrm{~cm}$ after plant removal with bulldozers.
\end{abstract}

Index terms: Geostatistics, soil fertility, traditional management, semivariogram.

\footnotetext{
${ }^{(1)}$ Recebido para publicação em dezembro de 2008 e aprovado em julho de 2009.

(2) Pesquisador Científico do Instituto Agronômico - IAC. Caixa Postal 28, CEP 13020-902 Campinas (SP). E-mails: sidney@iac.sp.gov.br; mkchiba@iac.sp.gov.br; cantarella@iac.sp.gov.br

(3) Mestrando em Agricultura Tropical e Subtropical, IAC. E-mail: osvaldoguedes@yahoo.com.br
} 


\title{
RESUMO: VARIABILIDADE ESPACIAL DOS ATRIBUTOS QUÍMICOS DO SOLOAPÓS REMOÇÃO DE CAFEZAL
}

\begin{abstract}
A avaliação da variabilidade espacial dos atributos químicos do solo tem se tornado importante ferramenta na determinação de estratégias de manejo que visam aumentar a produtividade agricola com menor degradação ambiental. O presente trabalho foi realizado no Centro Experimental Central do Instituto Agronômico, localizado em Campinas / SP, com o objetivo de caracterizar a variabilidade espacial dos atributos químicos de um Latossolo Vermelho após a remoção de um cafezal, cultivado por mais de 30 anos, com trator de esteira. As amostras de solo foram coletadas em grade georreferenciada de $20 \times 20 \mathrm{~m}$, totalizando 36 pontos nas camadas de 0-0,2 e 0,2-0,4 m, para determinação dos seguintes atributos químicos: $\mathrm{pH}$, matéria orgânica do solo (MOS), $\mathrm{K}^{+}, \mathrm{P}, \mathrm{Ca}^{2+}, \mathrm{Mg}^{2+}$, acidez potencial $(\mathrm{H}+\mathrm{Al}), \mathrm{N}-\mathrm{NH}_{4}$ e $\mathrm{N}$ $\mathrm{NO}_{3}$. A variabilidade espacial foi estudada utilizando-se a geoestatística, por meio da análise de semivariogramas e da interpolação por krigagem. Para todos os atributos estudados foi possivel estabelecer uma estrutura de dependência espacial definida por um semivariograma ajustado a um modelo esférico. Foram encontradas dependências espaciais de moderada a forte, com valores de alcance variando de 31 a $60 \mathrm{~m}$. Mesmo com a remoção das plantas com trator de esteira, foi possível mapear a variabilidade espacial dos atributos do solo nas camadas de 0-0,2 e 0,2-0,4 $m$ de profundidade.
\end{abstract}

Termos de indexação: geoestatística, fertilidade do solo, manejo convencional, semivariograma.

\section{INTRODUCTION}

Horizontal and vertical variation in the spatial distribution of soil properties results from the interaction of soil formation and management factors (Reichardt et al., 1986; Guimaraes et al., 2001; Cavalcante et al., 2007). Thus, even in pedologically homogeneous areas - with the same geomorphological surface, material of origin and climate - changes in soil use and management may lead to spatial variation in soil properties.

Nowadays, knowledge on the variability of soil properties is considered a basic principle for a localized management in precision agriculture for areas at any scale (Grego \& Vieira, 2005). Characterizing the spatial variability of the soil chemical properties, particularly in cultivated areas, provides relevant information for a more rational soil use and management (Montezano et al., 2006). Such studies gain particular importance in the case of mapping changes caused by different management methods (Carvalho et al., 1998; Carvalho et al., 2002). In such cases, characterizing the spatial variation of soil properties makes it possible to define differentiated management areas, which may increase the efficiency of fertilizer use and sampling schemes. Geostatistics has been used as an important and efficient strategic tool to characterize spatial variability for detailed soil analysis and description (Grego \& Vieira, 2005; Silva et al., 2007). Silva et al. (2007) concluded that the amplitude of chemical soil properties in coffee plantations justifies local and differentiated fertilizer use, and that mean values do not adequately reflect nutrient demands. Marked variations in nutrient levels and soil $\mathrm{pH}$ can be found frequently in cultivated fields, generally due to intensive cultivation and fertilizer use along the plantation rows (Werner, 2004).

Thus, the study hypothesis was that soil displacement due to coffee tree removal would result in spatial variations of soil chemical properties so that no spatial dependence structure could be established from the semivariograms. The purpose of this study was to characterize the spatial variability of chemical properties of a Latossolo Vermelho after bulldozing coffee trees off an over 30-year-old coffee plantation.

\section{MATERIAL AND METHODS}

This study was carried out at the Experimental Center of the Instituto Agronomico (Santa Elisa Farm), Campinas, Sao Paulo. According to Köeppen's climatic classification, the study site is a transition between the Cwa and Cfa climatic types: a tropical dry winter, wet summer, high-altitude $( \pm 600 \mathrm{~m})$ climate. The site - a Latossolo Vermelho - had been cultivated for over 30 years with coffee. In March 1984, plants were removed by passing a bulldozer with a front blade so that yearly crops could be established. After plant removal, soil samples were taken from a georeferenced regular 20 x 20 m grid based on plot limits (Figure 1) from the layers $0-0.2$ and $0.2-0.4 \mathrm{~m}$; the samples were air-dried, pounded to break up clods, sieved through a $2 \mathrm{~mm}$ diameter mesh, and analyzed for $\mathrm{pH}$, soil organic matter (SOM), exchangeable $\mathrm{K}^{+}, \mathrm{Ca}^{2+}$ and $\mathrm{Mg}^{2+}$, available $\mathrm{P}, \mathrm{H}+\mathrm{Al}, \mathrm{N}-\mathrm{NH}_{4}{ }^{+}$and $\mathrm{N}-\mathrm{NO}_{3}{ }^{-}$, as described by Raij \& Quaggio (1983). 


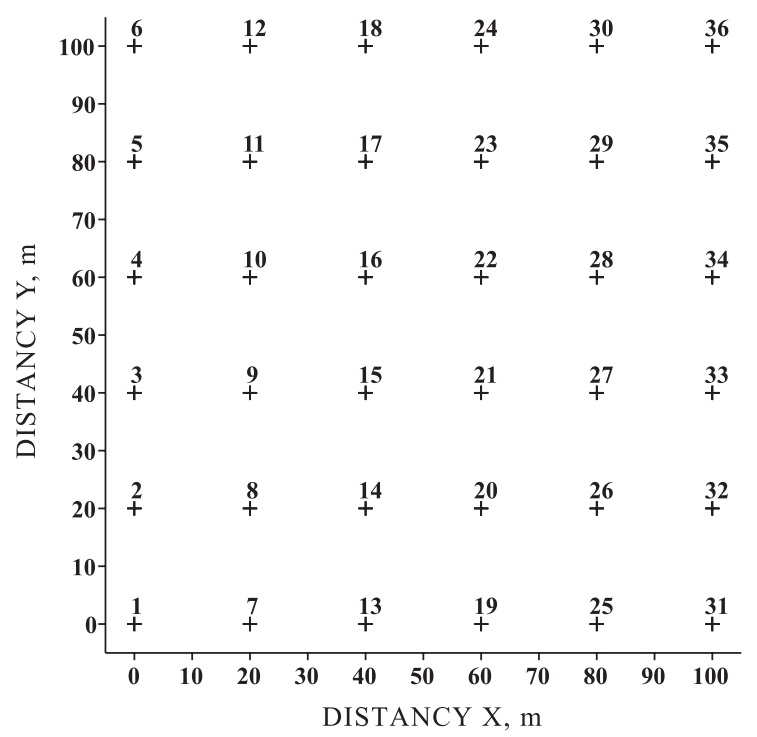

Figure 1. Sampling grid of the experimental area.

Descriptive statistical parameters (mean, variance, variation coefficients (VC), asymmetry and kurtosis) were calculated to check data dispersion and central tendency. Transformation procedures were applied to data that were initially not distributed normally. Data were analyzed by geostatistical methods (semivariogram calculation as described by Vieira, 2000) based on hypothetical intrinsic stationarity assumptions to study the spatial variability of soil properties. Semivariance $\gamma(\mathrm{h})$ was applied to calculate the partial autocorrelation among local neighbors, as shown in equation 1 :

$$
\gamma(h)=\frac{1}{2 N(h)} \sum_{i=1}^{N}\left[Z\left(x_{i}\right)-Z\left(x_{i}+h\right)^{2}\right]
$$

where $N(h)$ is the number of pairs of measured values $\mathrm{Z}\left(\mathrm{x}_{\mathrm{i}}\right)$ and $\mathrm{Z}\left(\mathrm{x}_{\mathrm{i}}+\mathrm{h}\right)$, separated by a vector $\mathrm{h}$, which is the distance defined by the coordinates $\mathrm{Z}\left(\mathrm{x}_{\mathrm{i}}\right)$ and $\mathrm{Z}\left(\mathrm{x}_{\mathrm{i}}+\mathrm{h}\right)$.

The spherical mathematical model was applied to spatially dependent semivariograms (equation 2).

$$
\begin{gathered}
\gamma(h)=C_{0}+C_{1}\left[\frac{3}{2} \cdot\left(\frac{h}{a}\right)-\frac{1}{2} \cdot\left(\frac{h}{a}\right)^{3}\right] ; 0<h<a \\
\gamma(h)=\mathrm{C}_{0}+\mathrm{C}_{1} ; h>a
\end{gathered}
$$

where $\mathrm{C}_{0}=$ nugget effect, the value of $\gamma(h)$ when $h=$ 0 , representing variation not explained by the model or by random variation; $a=$ reach of spatial dependence; $\mathrm{C}_{0}+\mathrm{C}_{1}=$ level, the value of $\gamma(h)$ based on the reach, and $\mathrm{C}_{1}=$ structural variance, the difference between the level and the nugget effect. Equation (2) generates $\gamma(h)$ values for the distances $h$; according to Vieira (2000), measurements done in close areas are expected to be similar, compared to measurements in more distant areas. Thus, $\gamma(h)$ will increase with $h$ until reaching a maximum value, after which it stabilizes at a level that corresponds to the distance limit of spatial dependence, the reach. Measurements over longer distances than the reach are randomly distributed, and are thus independent from each other. The degree of spatial dependence (GD), which measures the degree of the nugget effect $\left(\mathrm{C}_{0}\right)$ relative to the level $\left(\mathrm{C}_{0}+\mathrm{C}_{1}\right)$ (Cambardella et al., 1994), was applied to express the spatial dependence of a variable, and was calculated using equation (3).

$$
G D=\left(\frac{C_{0}}{C_{0}+C_{1}}\right) \cdot 100
$$

According to Cambardella et al. (1994), GD can be classified into strong (GD $<25 \%$ ), moderate $(26 \%<\mathrm{GD}<75 \%)$, and weak spatial dependence (GD $>75 \%$ ). After the spatial autocorrelation among samples had been demonstrated by semivariogram analysis, values with no tendencies and minimal variation were interpolated for non-sampled sites by the ordinary kriging method described by Vieira (2000). Descriptive statistics, semivariograms and kriging parameters were calculated as explained by Vieira et al. (2002). Contour maps were drawn using the SURFER 7.0 (Golden Software, 1999) software for handling and visualizing the spatial distribution of soil properties.

\section{RESULTS AND DISCUSSION}

Descriptive statistical analysis revealed that $\mathrm{P}, \mathrm{K}$, $\mathrm{Ca}, \mathrm{N}-\mathrm{NH}_{4}$, and $\mathrm{N}-\mathrm{NO}_{3}$ contents in both layers were not normally distributed (Guassian distribution), as shown by the Kolmogorov-Smirnov test $\mathrm{D}$ coefficient, at $5 \%$; rather, asymmetry coefficient values were above 1.0 (Table 1). According to Webster (2001), asymmetry values between 0.5 and 1.0 have a lognormal frequency distribution. Because logarithmic transformation did not adequately adjust all variables (data not shown), and a normal distribution is not needed for geostatistical analysis, outlying data - over 1.5 times the interquartile interval - were excluded (Figures 2 and 3). A similar procedure was applied to data from the 20-40 cm layer (Figure 3). The approximately normal adjustment was considered enough to avoid any distribution with very long tails and eventual issues with mean kriged values.

Based on the variation coefficient (VC) classification proposed by Gomes (1984), the only low VC soil property was $\mathrm{pH}$ (below $10 \%$ ) in both layers, supporting conclusions of Souza et al. (2004), Pontelli (2006) and Silva et al. (2007). This finding, however, was expected since this property has low variability. The VC of soil organic matter (SOM) reachd around moderate values $(10 \%<\mathrm{CV}<20 \%)$ in both sampled layers; the potential acidity $(\mathrm{H}+\mathrm{Al})$ in the $0-0.2 \mathrm{~m}$ layer had a high VC (> $30 \%$ ). The remaining chemical properties had very high VCs, ranging from $35 \%$ to 
Table 1. Descriptive statistics of soil chemical properties

\begin{tabular}{|c|c|c|c|c|c|c|c|c|c|}
\hline Variables & Unit & $\mathbf{n}$ & Mean & Var & SD & $\mathrm{VC}$ & $\mathrm{C}_{\mathrm{sk}}$ & $\mathrm{C}_{\mathbf{k}}$ & Prob. D ${ }_{\mathrm{K}-\mathrm{S}}$ \\
\hline & \multicolumn{9}{|c|}{$0.0-20 \mathrm{~cm}$} \\
\hline $\mathrm{P}^{*}$ & $\mathrm{mg} \mathrm{dm} \mathrm{m}^{-3}$ & 34 & 15.7 & 65.7 & 8.09 & 51.4 & 0.8 & 0.3 & $>0.15$ \\
\hline $\mathrm{pH}$ & s/unit & 36 & 4.5 & 0.1 & 0.3 & 6.0 & 1.3 & 1.9 & $>0.15$ \\
\hline MO & $\mathrm{g} \mathrm{dm} \mathrm{m}^{-3}$ & 36 & 47.3 & 59.1 & 7.7 & 16.3 & 1.2 & 2.1 & 0.06 \\
\hline $\mathrm{K}$ & $\mathrm{mmol}_{\mathrm{c}} \mathrm{dm}^{-3}$ & 36 & 3.9 & 4.8 & 2.2 & 56.4 & 0.4 & -1.2 & 0.10 \\
\hline $\mathrm{Ca}^{*}$ & $\mathrm{mmol}_{\mathrm{c}} \mathrm{dm}^{-3}$ & 34 & 20.8 & 51.0 & 7.14 & 34.3 & 0.9 & 0.1 & 0.02 \\
\hline $\mathrm{Mg}$ & $\mathrm{mmol}_{\mathrm{c}} \mathrm{dm}^{-3}$ & 36 & 8.1 & 8.3 & 2.9 & 35.5 & 0.7 & 0.3 & $>0.15$ \\
\hline $\mathrm{H}+\mathrm{Al}$ & $\mathrm{mmol}_{\mathrm{c}} \mathrm{dm}^{-3}$ & 36 & 57.1 & 242.5 & 15.6 & 27.3 & -0.6 & -0.1 & 0.14 \\
\hline $\mathrm{N}-\mathrm{NH}_{4}$ & $m g g^{-1}$ & 36 & 9.1 & 32.8 & 5.7 & 62.7 & 1.2 & 0.6 & 0.06 \\
\hline \multirow[t]{2}{*}{$\mathrm{N}-\mathrm{NO}_{3} *$} & $\mathrm{mg} \mathrm{g}^{-1}$ & 34 & 9.8 & 62.7 & 7.92 & 81.0 & 0.9 & 0.0 & 0.03 \\
\hline & \multicolumn{9}{|c|}{$20-40 \mathrm{~cm}$} \\
\hline $\mathrm{P}^{*}$ & $\mathrm{mg} \mathrm{dm} \mathrm{m}^{-3}$ & 33 & 3.8 & 1.2 & 1.11 & 29.2 & 0.4 & -0.4 & 0.01 \\
\hline $\mathrm{pH}$ & s/unit & 36 & 4.5 & 0.1 & 0.4 & 8.3 & 0.5 & -0.6 & $>0.15$ \\
\hline MO & $\mathrm{g} \mathrm{dm} \mathrm{m}^{-3}$ & 36 & 28.1 & 20.2 & 4.5 & 16.0 & 0.1 & -1.2 & 0.106 \\
\hline $\mathrm{K}^{*}$ & $\mathrm{mmol}_{\mathrm{c}} \mathrm{dm}^{-3}$ & 31 & 1.2 & 1.4 & 1.18 & 99.1 & 1.3 & 0.9 & $<0.01$ \\
\hline $\mathrm{Ca}$ & $\mathrm{mmol}_{\mathrm{c}} \mathrm{dm}^{-3}$ & 36 & 19.7 & 122.8 & 11.1 & 56.4 & 0.7 & -0.3 & $>0.15$ \\
\hline $\mathrm{Mg}$ & $\mathrm{mmol}_{\mathrm{c}} \mathrm{dm}^{-3}$ & 36 & 5.3 & 3.7 & 1.9 & 36.4 & 0.7 & 1.2 & $>0.15$ \\
\hline $\mathrm{H}+\mathrm{Al}$ & $\mathrm{mmol}_{\mathrm{c}} \mathrm{dm}^{-3}$ & 36 & 48.6 & 330.8 & 18.2 & 37.4 & 0.4 & -0.8 & $>0.15$ \\
\hline $\mathrm{N}-\mathrm{NH}_{4}$ * & $\mathrm{mg} \mathrm{g}^{-1}$ & 35 & 7.2 & 13.5 & 3.7 & 7.6 & 0.8 & -0.9 & $<0.01$ \\
\hline $\mathrm{N}-\mathrm{NO}_{3} *$ & $\mathrm{mg} \mathrm{g}^{-1}$ & 32 & 2.0 & 2.8 & 1.7 & 85.0 & 1.4 & 1.6 & $<0.01$ \\
\hline
\end{tabular}

Var: sample variance; SD: standard deviation; VC: variation coefficient; $\mathrm{C}_{\mathrm{sk}}$ : asymmetry coefficient; $\mathrm{C}_{\mathrm{k}}$ : curtosis coefficient; $\mathrm{D}_{\mathrm{K}-\mathrm{s}}$ : probability of the Kolmogorov-Smirnov test for normal distribution $(\mathrm{p}>0.05)$.

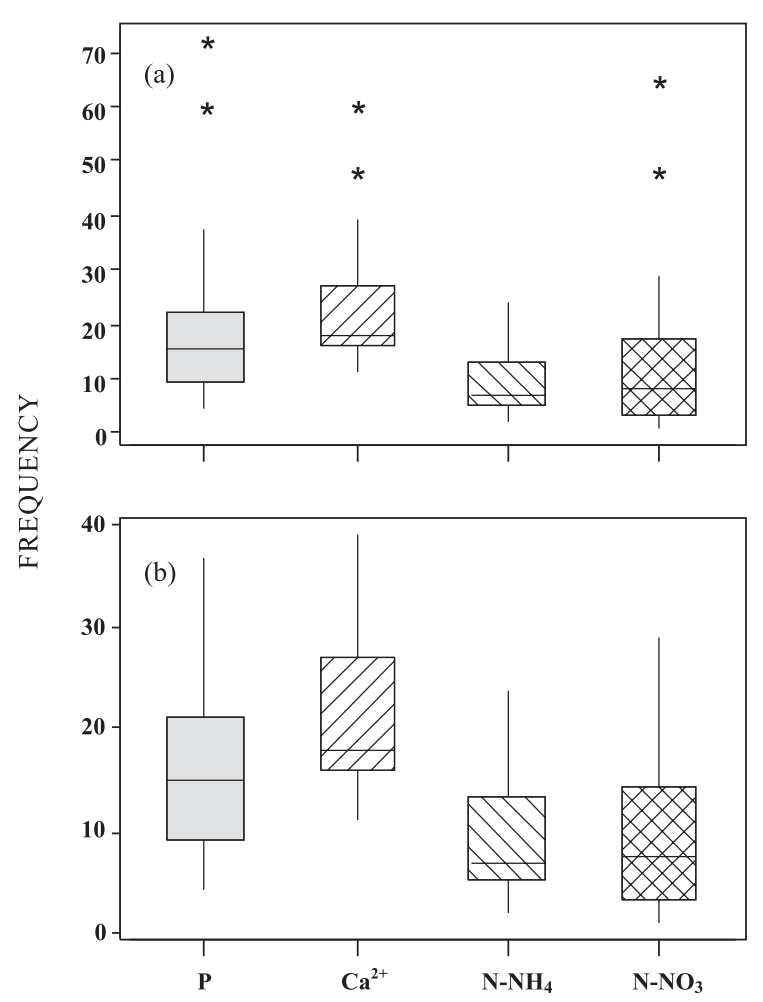

Figure 2. Boxplot of data from the 0-20 cm layer with outlying data (a) and after removal of such data (b).

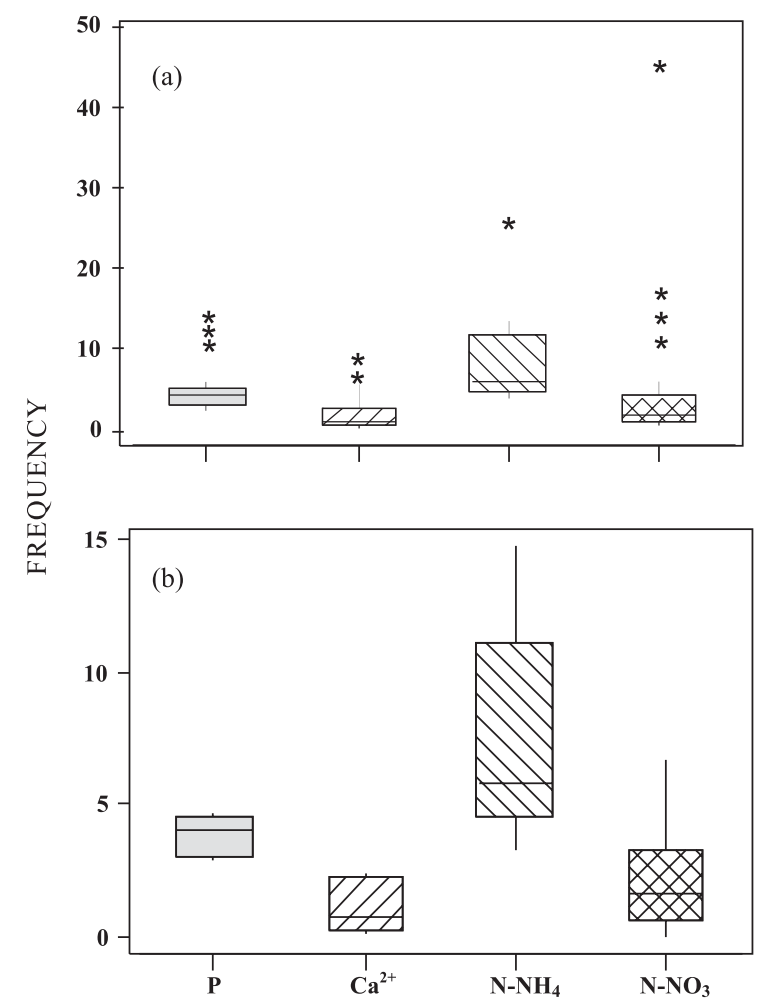

Figure 3. Boxplot of data from the $20-40 \mathrm{~cm}$ layer with outlying data (a) and after removal of such data (b). 
about $190 \%$. The reach of $\mathrm{N}-\mathrm{NO}_{3}$ was wider than of other values in both layers: $\mathrm{VC}=108.6 \%$ in the 0 $0.2 \mathrm{~m}$ layer and $189.9 \%$ in the $0.2-0.4$ m layer. Being an anion, $\mathrm{NO}_{3}{ }^{-}$is more mobile because of repulsion forces from predominant negative electrical charges in weathered and acid soils, typical of the soil used in this study. Many factors may cause high VC values: residual effects from previous fertilization, type of sampling scheme, and/or exposure of nutrient-poor soils due to surface erosion (Salviano et al., 1998; Montezano et al., 2006; Cavalcante et al., 2007). The expectation was that the soil movement caused by coffee tree removal would cause soil property variations at a scale that would not allow the establishment of any spatial correlation structure.

All chemical properties studied had a defined spatial dependence; semivariograms were adjusted to the spherical mathematical model (Table 2), except for $\mathrm{pH}$ and $\mathrm{Mg}$ values, which had a pure nugget effect (PNE) in the $0.2-0.4 \mathrm{~m}$ depth layer. The semivariograms were adjusted to the spherical model since this model suits soil property analysis best (Carvalho et al., 2003; Cavalcante et al., 2007; Zanão Junior et al., 2007; Siqueira et al., 2008); it also invalidates the hypothesis that such an adjustment would not be possible following soil movement by coffee tree removal. A mathematical model with at least 30 data pairs per point was used for the experimental semivariogram

Table 2. Determination coefficient of the spherical model adjusted to semivariograms and spatial dependence of the model

\begin{tabular}{lccc}
\hline Variable & $\mathbf{R}^{2}$ & & GD (\%) \\
\hline & & $0.0-0.2 \mathrm{~m}$ & \\
$\mathrm{P}$ & 0.97 & & 42 \\
$\mathrm{pH}$ & 0.83 & & 0 \\
$\mathrm{SOM}$ & 0.97 & & 37 \\
$\mathrm{~K}$ & 0.77 & & 19 \\
$\mathrm{Ca}$ & 0.99 & & 40 \\
$\mathrm{Mg}$ & 0.98 & & 40 \\
$\mathrm{H}+\mathrm{Al}$ & 0.93 & & 17 \\
$\mathrm{~N}-\mathrm{NH}_{4}$ & 0.76 & & 16 \\
$\mathrm{~N}-\mathrm{NO}_{3}$ & 0.85 & & 19 \\
& & $0.2-0.4 \mathrm{~m}$ & $\mathrm{~m}$ \\
$\mathrm{P}$ & 0.89 & & 44 \\
$\mathrm{pH}$ & & $\mathrm{PNE}$ & \\
$\mathrm{SOM}$ & 0.97 & & 10 \\
$\mathrm{~K}$ & 0.71 & & 53 \\
$\mathrm{Ca}$ & 0.93 & & 43 \\
$\mathrm{Mg}$ & & $\mathrm{PNE}$ & \\
$\mathrm{H}+\mathrm{Al}$ & 0.86 & & 26 \\
$\mathrm{~N}-\mathrm{NH}_{4}$ & 0.84 & & 40 \\
$\mathrm{~N}-\mathrm{NO}_{3}$ & 0.97 & & 37
\end{tabular}

$\mathrm{R}^{2}$ : adjusted determination coefficient of the model; GD: degree of spatial dependence; PNE: pure nugget effect; SOM: organic matter. calculations, since this amount is sufficient for a robust estimate (Landim, 2003).

The nugget effect $\left(\mathrm{C}_{0}\right)$ reflects variability not explained by semivariograms for distances below the separation distance between samples (Vieira, 2000). Lower $\mathrm{C}_{0}$ values were found for $\mathrm{pH}, \mathrm{K}^{+}, \mathrm{Mg}^{2+}$ and $\mathrm{N}$ $\mathrm{NH}_{4}$ in the 0-20 cm layer, and for SOM, K, $\mathrm{P}$ and $\mathrm{N}$ $\mathrm{NH}_{4}$ in the $0.2-0.4 \mathrm{~m}$ layer (Figures 4 and 5). Potassium and $\mathrm{N}-\mathrm{NH}_{4}$ had low $\mathrm{C}_{0}$ values in both layers, indicating higher continuity of spatial variability compared to the other chemical properties (Figures 4 and 5). These elements, however, are relatively mobile in soil, and the measured spatial dependence structure is valid only for a short time period after soil sampling. Soil humidity and oxidoreduction potentials affect both $\mathrm{K}$ dynamics and forms of soil N (Havlin et al., 1998).

Besides these variations there may be sampling errors, local variation, analytical mistakes, and other errors that make individual identification impracticable. It may therefore be easier to compare the study variables by representing random variation as a percentage. Analysis of the $\mathrm{C}_{0} /\left(\mathrm{C}_{0}+\mathrm{C}_{1}\right)$ ratio makes it possible to quantify the random component $\left(\mathrm{C}_{0}\right)$ within total variance $\left(\mathrm{C}_{0}+\mathrm{C}_{1}\right)$, and is referred to as the degree of spatial dependence (GD). The spatial dependence of all chemical properties in this study was classified as strong or moderate, according to the classification of Cambardella et al. (1994). Other authors have reported similar results, which highlights the importance of knowing spatial dependence structures (Silva et al., 2003; Machado et al., 2007; Zanão Junior et al., 2007). Strong spatial dependence (GD < $25 \%$ ) of soil properties at a depth of $0-0.2 \mathrm{~m}$ shows that even coffee tree removal with bulldozers did not displace the soil to such a degree as to cause a completely random spatial distribution of these properties in the study area (Table 2).

As with the findings in the $0-0.2 \mathrm{~m}$ layer, higher $\mathrm{C}_{0}$ values for $\mathrm{K}^{+}, \mathrm{Ca}^{2+}$ and $\mathrm{Mg}^{2+}$ in the $0.2-0.4$ m layer probably result from a local application of these inputs in the shadow of the coffee tree crown for 30 years; subsequent dilution and dispersal by water in the soil profile would result in different amounts of these substances at different sampling points within the study area (Chen \& Gabelman, 2000; Caires et al., 2001).

The reach of spatial dependence $(a)$ indicates the distance from which variance becomes constant even with further increases in sampling point intervals (Journel \& Huijbregts, 1991), and may be used in defining sampling procedures more effectively. Reach intervals for $\mathrm{Ca}^{2+}$ and $\mathrm{K}^{+}$in the surface layers were 60 and $31 \mathrm{~m}$ each. In the $20-40 \mathrm{~cm}$ layer, the reach was $40 \mathrm{~m}$ for $\mathrm{P}$ and $59 \mathrm{~m}$ for $\mathrm{H}+\mathrm{Al}$. Thus, the $20 \mathrm{~m}$ distance between samples used in this study was enough to detect the spatial variability of soil properties; furthermore, sampling at a distance of up to $30 \mathrm{~m}$ may be used for similar variability estimates. 


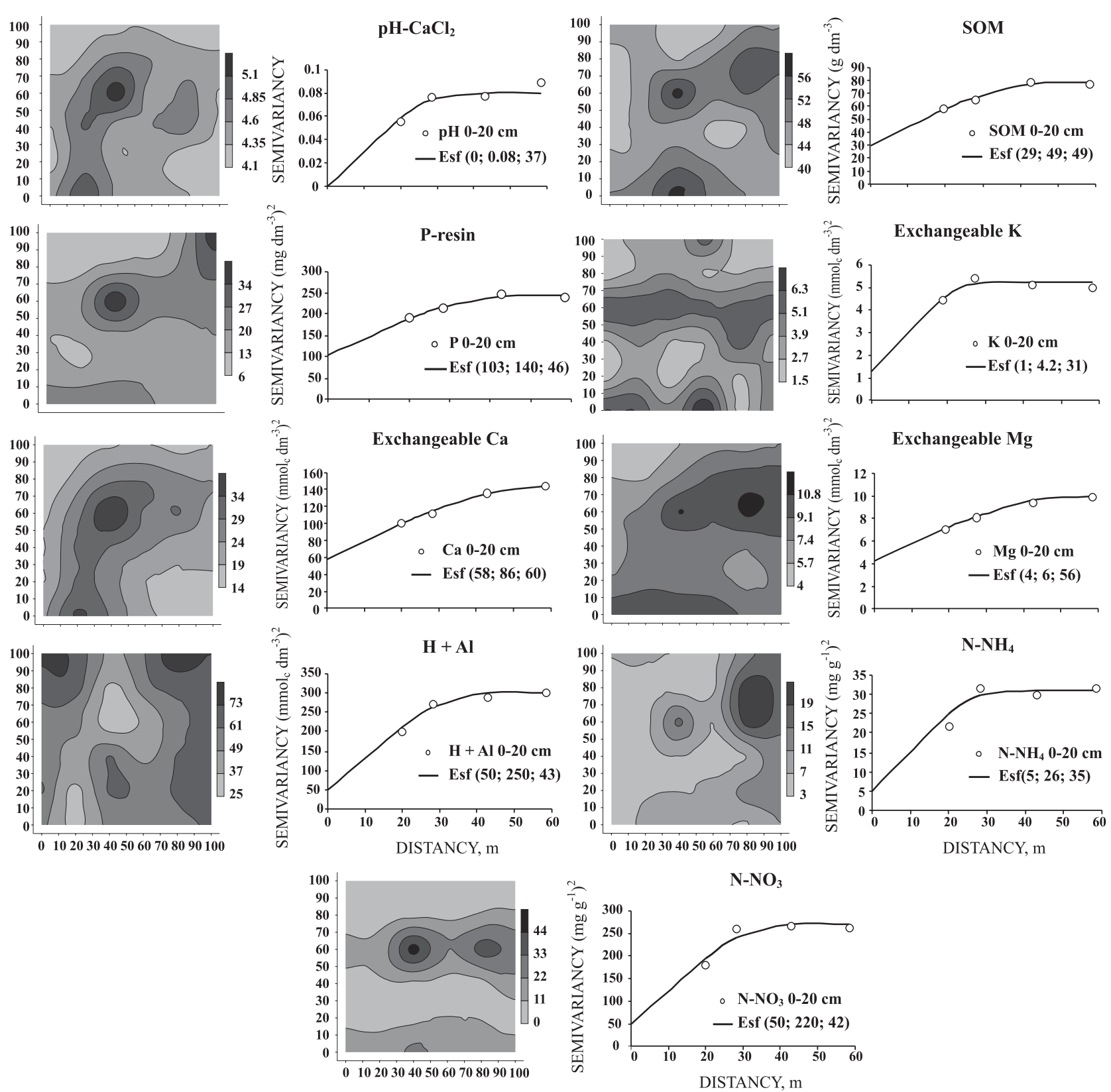

Figure 4. Spatial variability maps and semivariograms of soil chemical properties in the 0-0.2 m layer. (Modelo; $\left.\mathrm{C}_{0} ; \mathrm{C}_{1} ; \mathrm{a}\right)$.

A visual map analysis showed that at a depth of 0-0.2 m, clear and gradual areas predominated for all soil properties (Figure 4). The $\mathrm{pH}$ reachd from 4.1 to 5.3 , with most values remaining below 4.8 in nearly the entire area, which defines soil reaction as acid. Values of P reachd from 4 to $37 \mathrm{mg} \mathrm{dm}^{-3}$, showing that this nutrient was present at low and medium levels in most of the area; mean $\mathrm{K}^{+}$and $\mathrm{Mg}^{2+}$ amplitude values reachd from 1.5 to $7.5 \mathrm{mmol}_{\mathrm{c}} \mathrm{dm}^{-3}$ and 4 to $12.5 \mathrm{mmol}_{\mathrm{c}} \mathrm{dm}^{-3}$. The $\mathrm{Ca}^{2+}$ values (11 to $39 \mathrm{mmol}_{\mathrm{c}} \mathrm{dm}^{-3}$ ) were high, according to the soil criteria for the State of São Paulo (Raij et al., 1997).

Integrated visual map analysis for both layers showed that a similarity degree between $\mathrm{pH}$, SOM,
$\mathrm{P}$, and $\mathrm{Ca}^{2+}$ maps (Figures 4 and 5). There was, however, no spatial distribution similarity between $\mathrm{N}-\mathrm{NH}_{4}$ and $\mathrm{N}-\mathrm{NO}_{3}$ in both layers. The upper right portion of the study area had higher $\mathrm{N}-\mathrm{NH}_{4}$ values at both depths. The $\mathrm{N}$ limits in the maps may vary, due to the rapid transformation of these $\mathrm{N}$ forms in the soil (Moreira \& Siqueira, 2002).

The subsoil chemical status for root growth was diagnosed in a sample analysis of the 0.2-0.4 m layer (Raij et al., 1997). Calcium values in this layer should be above $4 \mathrm{mmol}_{\mathrm{c}} \mathrm{dm}^{-3}$, whereas the Ca map analysis (Figure 5) showed that this element reachd from 5 to $46 \mathrm{mmol}_{\mathrm{c}} \mathrm{dm}^{-3}$, i.e., the levels of this nutrient exceeded the level considered critical for plant development by 

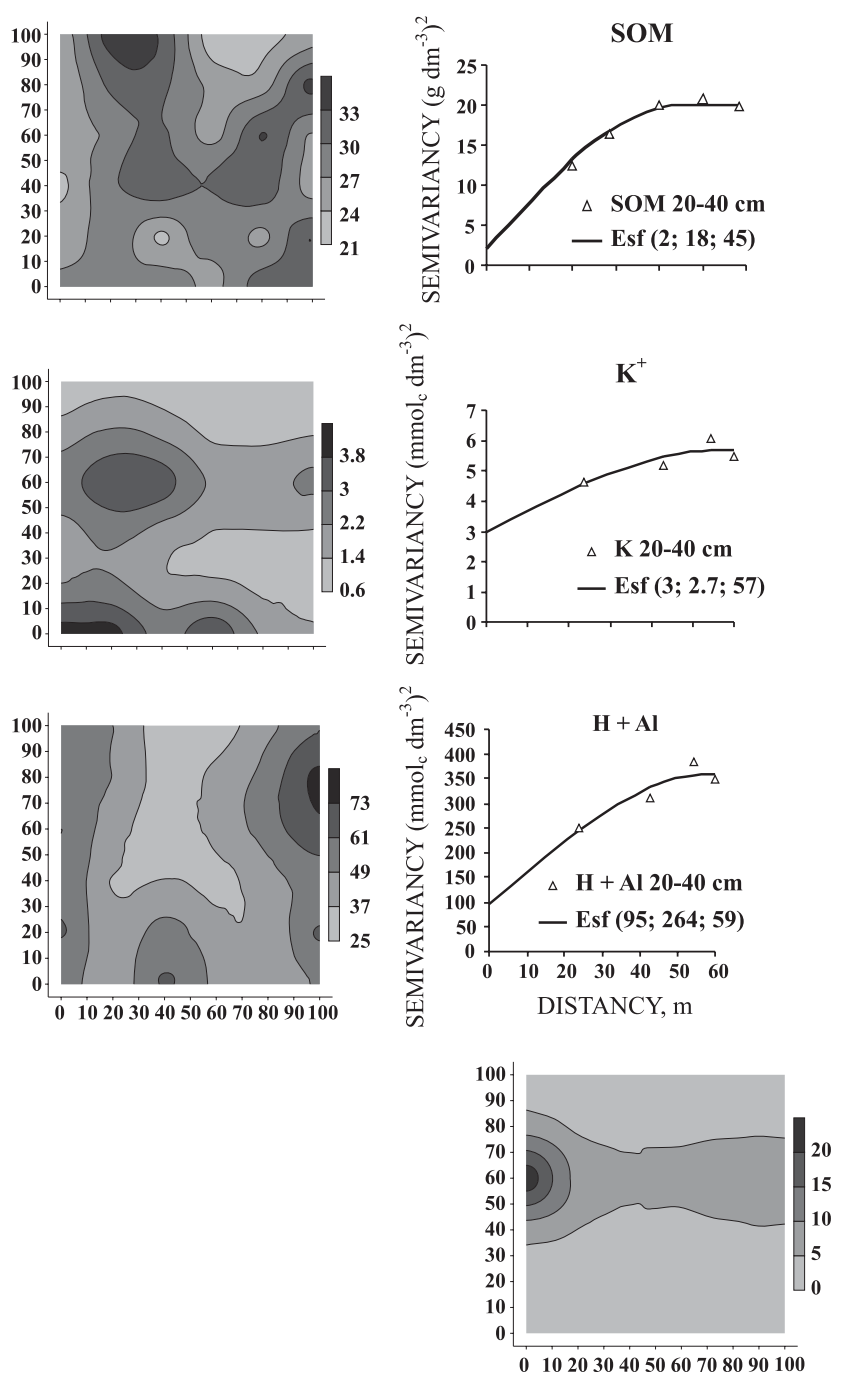

Figure 5. Spatial variability maps of soil properties in the $0.2-0.4 \mathrm{~m}$ layer. $M o d e l\left(C_{0} ; C_{1} ; a\right)$.

far. Defining areas with soil property variations of this amplitude justifies investments in soil mapping, since locally adjusted inputs may result in savings and increased productivity.

A comparison of maps for each soil property at both depths revealed that the spatial distribution of $\mathrm{H}+\mathrm{Al}$ and $\mathrm{N}-\mathrm{NH}_{4}$ was similar. Soil displacement due to coffee tree bulldozing may have affected the spatial distribution of soil properties, as evidenced by the irregular spatial patterns of some properties; this was, however, not significant enough to affect the characterization of the spatial variability structure.

\section{CONCLUSION}

1. Removal of coffee trees with bulldozers did not result in a loss of the spatial dependence structure of the properties $\mathrm{P}, \mathrm{pH}, \mathrm{SOM}, \mathrm{K}^{+}, \mathrm{Ca}^{2+}, \mathrm{Mg}^{2+}, \mathrm{N}-\mathrm{NH}_{4}$, and $\mathrm{N}-\mathrm{NO}_{3}$ in the $0-0.2 \mathrm{~m}$ layer.
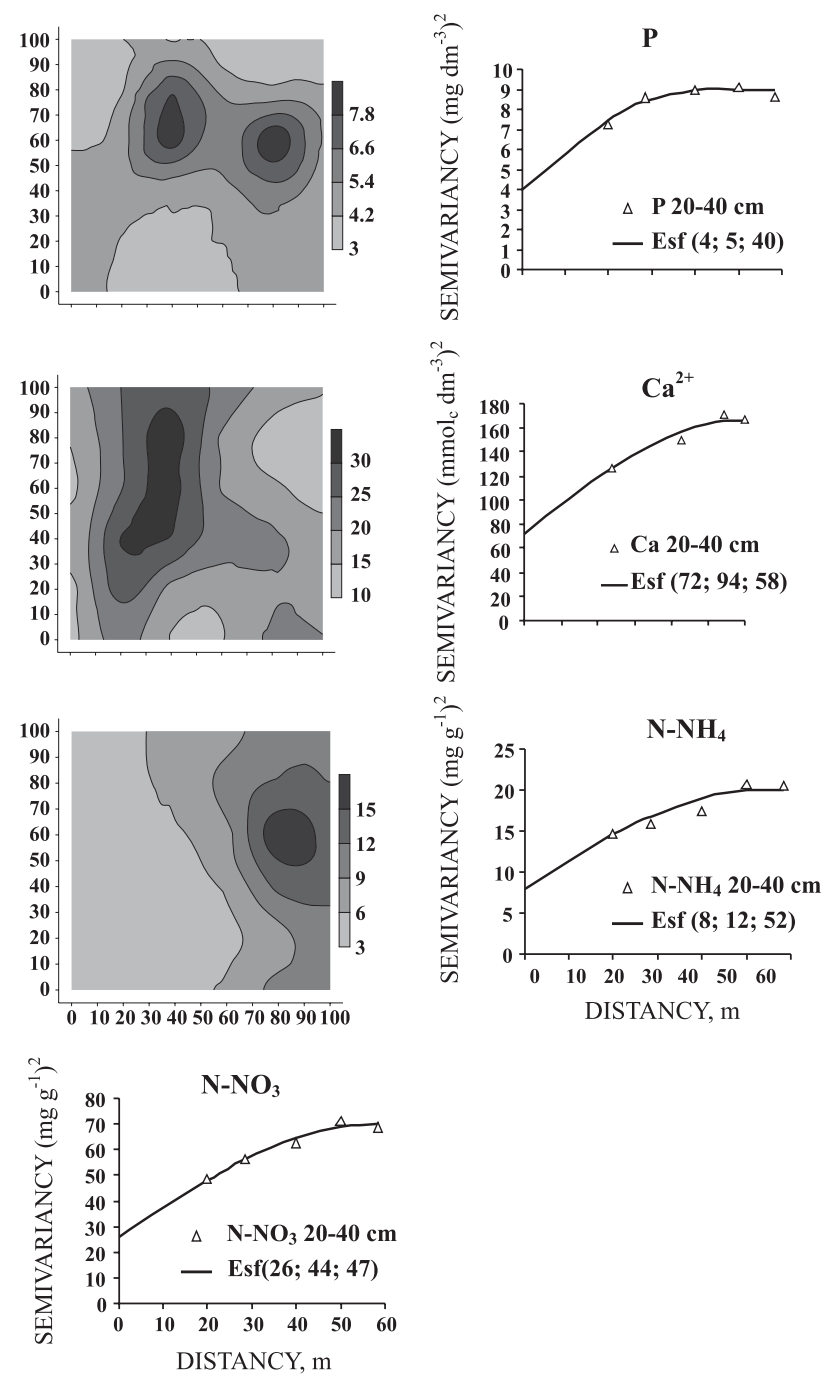

DISTANCY, $\mathrm{m}$

2. The spatial dependence structure observed made it possible to identify areas with different nutrient levels by kriging in both layers.

\section{LITEATURE CITED}

CAIRES, E.F.; BANZATTO, D.A. \& FONSECA, A.F. Calagem na superfície em sistema plantio direto. R. Bras. Ci. Solo, 24:161-164, 2001.

CAMBARDELLA, C.A.; MOOMAN, T.B.; NOVAK, J.M.; PARKIN, T.B.; KARLEN, D.L.; TURV, R.F. \& KONOPA, A.E. Field scale variability of soil properties in central Iowa soil. Soil Sci. Soc. Am. J., 47:1501-1511, 1994.

CARVALHO, J.R.P.; SILVEIRA, P.M. \& VIEIRA, S.R. Geoestatística na determinação da variabilidade espacial de características químicas do solo sob diferentes preparos. Pesq. Agropec. Bras., 37:11511159, 2002. 
CARVALHO, M.P.; TAKEDA, E.Y. \& FREGDI, O.S Variabilidade espacial de atributos de um solo sob videira em Vitória Brasil (SP). R. Bras. Ci. Solo, 27:695-703, 2003.

CARVALHO, O.S.; GASCÓ, J.M.; LOPEZ, F.G. \& REQUEJO, A.S. Variabilidade espacial de algumas propriedades químicas e físicas de um solo submetido a diferentes sucessões de cultivo. R. Bras. Ci. Solo, 22:497-503, 1998.

CAVALCANTE, E.G.S.; ALVES, M.C.; SOUZA, Z.M. \& PEREIRA, G.T. Variabilidade espacial de atributos químicos do solo sob diferentes usos e manejos. R. Bras.Ci. Solo, 31:1329-1339, 2007

CHEN, J. \& GABELMAN, W.H. Morphological and physiological characteristics of tomato roots associated with potassium-acquisition efficiency. Sci. Hortic., 83:213$225,2000$.

GOMES, F.P. A estatística moderna na pesquisa agropecuária. Piracicaba, POTAFÓS, 1984. 160p.

GOLDEN SOFTWARE - SURFER for windows. Release 7.0. Contouring and 3D surface mapping for scientist's engineers. User's guide. New York, Golden Software, 1999. $619 \mathrm{p}$

GREGO, C.R. \& VIEIRA, S.R. Variabilidade espacial de propriedades físicas do solo em uma parcela experimental. R. Bras. Ci. Solo, 29:169-177, 2005.

GUIMARAES, G.L.; SOUZA, Z.M.; SILVA, M.L.S.; CAMPOS, D.T.S.; CARVALHO, M.P. \& PEREIRA, G.T. Variabilidade espacial de atributos físicos em um Latossolo Vermelho distrófico sob semeadura direta em Selvíria (MS). R. Bras. Ci. Solo, 25:699-707, 2001.

HAVLIN, J.L.; TISDALE, S.L.; NELSON, W.L. \& BEATON, J.D. Soil fertility and fertilizers. 6. ed. New York, Prentice Hall, 1998. 499p.

JOURNEL, A.G. \& HUIJBREGTS, C.J. Mining geostatistics. London, Academic Press, 1991. 600p.

LANDIM, P.M.B. Análise estatística de dados geológicos. São Paulo, Universidade Estadual de São Paulo, 2003. 253p.

MACHADO, L.O.; LANA, A.M.Q.; LANA, R.M.Q.; GUIMARÃES, E.C. \& FERREIRA, C.V. Variabilidade espacial de atributos químicos do solo em áreas sob sistema plantio convencional. R. Bras. Ci. Solo, 31:591-599, 2007.

MONTEZANO, Z.F.; CORAZZA, E.J. \& MURAOKA, T. Variabilidade espacial da fertilidade do solo em área cultivada e manejada homogeneamente. R. Bras. Ci. Solo, 30:839-847, 2006.

MOREIRA, F.M.S. \& SIQUEIRA, J.O. Microbiologia e bioquímica do solo. Lavras, Universidade Federal de Lavras, 2002. 626p.

PONTELLI, C.B. Caracterização da variabilidade espacial das características químicas do solo e da produtividade das culturas utilizando as ferramentas de agricultura de precisão. Santa Maria, Universidade Federal de Santa Maria, 2006. 112p. (Tese de Mestrado)

RAIJ, B.van; CANTARELLA, H.; QUAGGIO, J.A. \& FURLANI, A.M.C. Recomendações de adubação e calagem para o Estado de São Paulo. 2.ed. Campinas, Instituto Agronômico/Fundação IAC, 1997. 285p. (Boletim Técnico, 100
RAIJ, B.van \& QUAGGIO, J.A. Métodos de análise de solo para fins de fertilidade. Campinas, Instituto Agronômico de Campinas, 1983. 39p. (Boletim Técnico, 81)

REICHARDT, K.; VIEIRA, S.R. \& LIBARDI, P.L. Variabilidade espacial de solos e experimentação de campo. R. Bras. Ci. Solo, 10:1-6, 1986.

SALVIANO, A.A.C.; VIEIRA, S.R. \& SPAROVEK, G. Variabilidade espacial de atributos de solo e de Crotalaria juncea (L.) em área severamente erodida. R. Bras. Ci. Solo, 22:115-122, 1998.

SILVA, F.M.; SOUZA, Z.M.; FIGUEIREDO, C.A.P.; MARQUES JUNIOR, J. \& MACHADO, R.V. Variabilidade espacial de atributos químicos e da produtividade na cultura do café. Ci. Rural, 37:401-407, 2007.

SILVA, V.R.; REICHERT, J.M.; STORCK, L. \& FEIJÓ, S. Variabilidade espacial das características químicas do solo e produtividade de milho em um Argissolo VermelhoAmarelo distrófico arênico. R. Bras. Ci. Solo, 27:10131020, 2003.

SIQUEIRA, G.M.; VIEIRA, S.R. \& CEGDIA, M.B. Variabilidade espacial de atributos físicos do solo determinados por métodos diversos. Bragantia, 67:693-699, 2008.

SOUZA, Z.M.; BARBIERI, D.M.; MAQUES JÚNIOR, J.; PEREIRA, G.T. \& CAMPOS, M.C.C. Influência da variabilidade espacial de atributos químicos de um Latossolo na aplicação de insumos para cultura da canade-açúcar. Ci. Agrotec., 31:371-377, 2007.

SOUZA, Z.M.; MARQUES JUNIOR, J. \& PEREIRA, G.T. Variabilidade espacial de atributos físicos do solo em diferentes formas de relevo sob cultivo de cana-de-açúcar. R. Bras. Ci. Solo, 28:937-944, 2004.

VIEIRA, S.R. Geoestatística em estudos de variabilidade espacial do solo. In: NOVAIS, R.F.; ALVAREZ V., V.H. \& SCHAEFER, G.R., eds. Tópicos em ciência do solo. Viçosa, MG, Sociedade Brasileira de Ciência do Solo, 2000. v.1. p.1-54.

VIEIRA, S.R.; MILLETE, J.; TOPP, G.C. \& REYNOLDS, W.D. Handbook for geostatistical analysis of variability in soil and climate data. In: ALVAREZ V., V.H.; SCHAEFER, C.E.G.R.; BARROS, N.F.; MELLO, J.W.V. \& COSTA, J.M., eds. Tópicos em ciência do solo. Viçosa, MG, Sociedade Brasileira de Ciência do Solo, 2002. v.2. p.1-45.

WEBSTER, R. Statistics to support soil research and their presentation. Eur. J. Soil Sci., 52:331-340, 2001.

WERNER, V. Utilização de recursos de agricultura de precisão na geração de mapas de atributos, mapas de produtividade e aplicação de insumos a taxas variáveis. Santa Maria, Universidade Federal de Santa Maria, 2004.125p. (Tese de Mestrado)

ZANÃO JÚNIOR, L.A.; LANA, M.R.Q. \& GUIMARÃES, E.C. Variabilidade espacial do $\mathrm{pH}$, teores de matéria orgânica e micronutrientes em profundidades de amostragem num Latossolo Vermelho sob semeadura direta. Ci. Rural, $37: 1000-1007,2007$. 